\title{
An Investigation into the Change in Customer Complaints about Takeaway during Covid-19
}

\section{Covı-19 Sürecinde Paket Yemek Müşteri Şikâyetlerindeki Değişim Üzerine Bir Araştırma}

\section{Mehmet ŞİMŞEK ${ }^{\mathrm{a}}$ *}

${ }^{a}$ Dr. Öğr. Üyesi, Giresun Üniversitesi, Turizm Fakültesi, Gastronomi ve Mutfak Sanatları Bölümü, Giresun / TÜRKIYE ORCID ID: 0000-0002-7558-5010

\section{A K A L E B İLGİ İ}

Makale Geçmişi:

Başvuru tarihi: 12 Haziran 2020

Kabul tarihi: 6 Ağustos 2020

Anahtar Kelimeler:

COVID-19,

Paket yemek,

Müşteri şikâyeti,

Tüketici davranışı

\section{A R T ICLE INFO}

Article History:

Received June 12, 2020

Accepted August 6, 2020

\section{Keywords:}

COVID-19,

Takeaway,

Customer complaint,

Consumer behaviour

\begin{abstract}
ÖZ
Bu çalışmada COVID-19 sürecinde paket yemek müşteri şikâyetlerindeki değişim incelenmiştir. Çalışmanın verileri www.sikayetvar.com.tr sitesinde, www.yemeksepeti.com üzerinden çevrimiçi yemek siparişi veren müșterilerin șikâyetleri taranarak elde edilmiștir. Calıșmanın amacına yönelik anlamlı istatistiki sonuçlara ulaşabilmek amaciyla 21 Mart 2020 tarihinden geriye doğru 400 ve ileriye doğru 400 olmak üzere toplamda 800 şikâyet kaydı taranmıştır. Taranan veriler COVID-19 öncesi ve COVID-19 süreci olarak iki grupta düzenlenerek kodlamaya tabi tutulmuştur. Konuya yönelik literatürde yer alan çalışmalar ıșığında olușturulan kodlar sırasıyla, ödeme, hız, lezzet, hijyen, sağlık, ısı, eksik teslimat, davranış ve iade olarak belirlenmiş̧ir. Yapılan frekans analizine göre COVID-19 öncesi müşteri şikayetlerinde ilk beş sırayı davranış, ödeme, hız, iade ve eksik teslimat alırken, COVID-19 sürecinde bu sıralamanın lezzet, hijyen, hız, sağlık ve 1sı olarak sıralandığı tespit edilmiştir. Müşteri şikâyetlerinin COVID-19 sürecinde cinsiyete göre değişim yüzdelerinde oluşan en büyük farkın sırasıyla sağlık, hız ve hijyen konularında olduğu ve kadınların bu konularda erkeklere oranda daha duyarlı olduğu belirlenmiştir.
\end{abstract}




\section{GENIŞLETILMIŞ ÖZET}

Korona virüsün (COVID-19) Aralık 2019 tarihinde ortaya çıktığı, başlangıçta hayvandan insana bulaştığı sonrasında ise insandan insana damlacık veya temas yoluyla bulaşarak yayıldığı iddia edilmektedir. Ülkelerin COVID-19 salgınına karşı hazırlıksız olması bu nedenle de alınacak tedbirlerde bazı gecikme ve karmaşaların yaşanması, ilave olarak hastalığın bulaşma hızının yüksek olması sebebiyle epidemik yayılımın pandemiye dönüştüğü görülmüştür.

Beklenmedik bir hızla tüm dünyayı etkisi altına alan COVID-19'a karşı̈ ülkeler yayılımı durdurmak ve kendi izolasyonlarını sağlamak için sınırlarını kapatmış, ülke içinde serbest dolaşımı sınırlandırmış ve böylece sosyokültürel etkileşimi en aza indirmeye çalışmışlardır. Türkiye'de de COVID-19'a yönelik bazı radikal tedbirler alınmış ve alınmaya da devam edilmektedir. Bu tedbirlerin başında seyahat kısıtlaması, belirli yaş aralığında olan (65 yaş üstü ve 20 yaş altı) vatandaşlara sokağa çıkma yasağı, virüsün yaygın olduğu yerlerin karantina altına alınması, bir çok işyerinin geçici olarak kapatılması, sosyal izolasyon, herhangi bir nesneye ve/veya insana temas etmeme ve sosyal mesafe gelmektedir.

Alınan bu radikal ve olağanüstü tedbirlerin insanların yaşam biçimi, alışkanlıkları ve davranışlarında bazı değişimlere sebep olması kaçınılmazdır. Bu değişimlerden birinin de paket yemek siparişi alışkanlıklarında olduğu düşünülmektedir. Çünkü yukarıda söz edildiği üzere birçok işletmenin faaliyeti geçici olarak durdurulmuştur. Bu işletmelerin başında da yiyecek içecek işletmeleri gelmektedir. Söz konusu yiyecek içecek işletmelerinin yerinde hizmet vermesi askıya alınmış, sadece paket yemek hizmeti vermelerine müsaade edilmiştir. Gerek sokağa çıkma kısıtlamaları, gerekse yiyecek içecek işletmelerinin sadece paket servis hizmeti vermelerine müsaade edilmesi insanların evden paket yiyecek içecek sipariş verme sıklığını arttırdığı tahmin edilmektedir.

COVID-19 öncesinde de paket yemek hizmeti veren yiyecek içecek işletmelerinin bu süreçte yukarda bahsedilen sebeplerden ötürü faaliyetlerinin artmış olması kaçınılmazdır. Öte yandan paket yemek hizmetine ilk defa zorunlu olarak COVID-19 sebebiyle başlayan işletmelerin acemiliklerinden kaynaklanan bazı eksiklik ve aksaklıkların olması da doğaldır. Yine COVID-19 sürecinde müşterilerin özellikle hijyen, sağlıklı, ödeme ve teslim hızına yönelik beklentilerindeki hassasiyetlerinin artma olasılığı öngörülebilir bir gerçektir. Söz konusu bu ve benzeri sebepler nedeniyle müşteri şikâyetlerinde de bu dönemde bir değişimin olabileceği varsayılmaktadır. Bu bakış açısından hareketle bu çalışma kapsamında paket yemek hizmeti alan müşterilerin şikâyetlerinin COVID-19 sürecinde değişip değişmediği, değişti ise hangi yönde değişim gösterdiği incelenmiştir.

Araştırmada yöntem olarak kodlamaya dayalı içerik analizi kullanılmıştır. Çalışma kapsamında öncelikle tüketicilerin şikayetlerini çevrimiçi olarak kaydettikleri internet sitelerinden en etkili olan www.sikayetvar.com.tr sitesinde, www.yemeksepeti.com üzerinden yemek siparişi veren müşterilerin şikâyetleri taranmıştır. Taramanın yapıldığ tarih itibarıyla söz konusu sitede konuyla ilgili toplamda 3138 şikâyet kaydının olduğu görülmüştür. Çalışmanın amacına yönelik anlamlı istatistiki sonuçlara ulaşabilmek amacıyla 21 Mart 2020 tarihinden geriye doğru 400 ve ileriye doğru da 400 olmak üzere toplamda 800 şikâyet kaydı taranmıştır. Tarih olarak 21 Mart 2020'nin alınmasının amacı, bu tarih itibarıyla Türkiye'de COVID-19 sürecinin başlamış olduğu varsayımıdır. Tarama sürecinde şikâyet kaydında bulunan kullanıcıların isimlerinden cinsiyetleri belirlenmeye çalışılmış, böylelikle müşteri şikâyetlerinin cinsiyet anlamında farklılık gösterip göstermediğinin incelenebileceği varsayılmıştır. Ulaşılan şikâyetler COVID-19 öncesi ve COVID-19 süreci olarak iki grupta düzenlenerek ayrı ayrı kodlamaya tabi tutulmuştur. Bu süreçte kodlama yapılırken literatürdeki ilgili çalışmalardan yararlanılmıştır. Söz konusu çalışmalar ışığında taranan şikâyet kayıtları toplam 9 kod altında toplanmıştır. Bu kodlar sırasıyla, ödeme, hız, lezzet, hijyen, sağlık, 1sı, eksik teslimat, davranış ve iade olarak belirlenmiştir.

Araştırmada COVID-19 öncesine yönelik yapılan taramada 400 şikâyet kaydına 49 günde, COVID-19 sürecine yönelik yapılan taramada ise 400 şikâyet kaydına 38 günde ulaşılmıştır. Bu durum COVID-19 sürecinde müşteri şikâyet kayıtlarının arttığını göstermektedir. $\mathrm{Bu}$ artış paket yemek hizmeti veren işletmelerde yaşanan iş yoğunluğundan kaynaklanmış olabileceği gibi, bu olağanüstü süreçte müşterilerde oluşan bazı hassasiyetlerden kaynaklı da olabilir. Paket yemek hizmeti veren işletmelerin müşteri memnuniyet ve müşteri bağlılığı açısından son derece önemli olan bu şikâyet artışını göz ardı etmemeleri, söz konusu şikâyetlerle ilgili aksaklıkları tespit edip derhal ortadan kaldırmaya yönelik çalışmalar yapmaları önerilmektedir.

Verilere yönelik yapılan analiz sonucuna göre COVID-19 sürecinde şikâyet kaydında bulunan erkeklerin sayısı 288'den 267'ye gerilerken, kadınların sayısı 112'den 133'e yükselmiştir. Bu durum kadın müşterilerin COVID-19 sürecinde özellikle sağlık ve hijyene yönelik hassasiyetlerinden kaynaklı olabilir. Paket yemek hizmeti veren işletmelere bu süreçte ve devamında sağlık ve hijyen konularına daha fazla özen göstermeleri önerilebilir. Öte yandan araştırmacılara COVID-19 süreci sona erdiğinde benzer çalışmalar yaparak sonuçları karşılaştırmaları önerilmektedir.

Tüketicilerin şikayet sıralamasına yönelik yapılan analiz sonucuna göre ise COVID-19 öncesi müşteri şikâyet sıralamasında ilk dört sırayı davranış, ödeme, hız ve iadenin aldığı, COVID-19 sürecinde bu sıralamanın lezzet, hijyen, hız ve sağlık olarak değiştiği belirlenmiştir. $\mathrm{Bu}$ değişimin yaşanan olağanüstü sürecin etkisiyle müşterilerde sağlık ve hijyene yönelik hassasiyetten ve yine aynı süreçte paket yemek hizmeti veren işletmelerde yaşanan yoğunluktan kaynaklanabileceği tahmin edilmektedir. Bu bağlamda işletmelere yoğunluğu karşılamaya çalışırken sağlık ve hijyenden ödün vermemeleri, öte yandan çalışanlarının gerek çalışma saatlerini gerekse çalışma koşullarını ihmal etmemeleri, onların motivasyonlarını arttırıcı maddi ve manevi uygulamaları devreye sokmaları önerilmektedir. Araştırmacılara Paket yemek hizmetinde çalışanların işe bağlılık ve motivasyon düzeyleri ile işten ayrılma ve/veya tükenmişlik düzeyleri konularında çalışmalar yaparak sonuçları karşılaştırmaları önerilmektedir.

COVID-19 sürecinde müşteri şikayeti konularının cinsiyete göre sıralamasındaki farka yönelik yapılan analize göre en önemli farkın sağlık, hijyen ve hız konularında meydana geldiği tespit edilmiştir. Bu farkın kadın müşteriler lehinde olduğu bu nedenle paket yemek hizmeti veren işletmelerin zaten dikkat etmeleri gereken bu konulara, özellikle kadın müşterilerin siparişi sürecinde azami özen göstermeleri önerilmektedir.

Çalışma kısıtlı sürede ve müşterilerin çevrimiçi şikâyet kayıtlarının içerik analiziyle yapılmıştır. Araştırmacılara konuya yönelik saha çalışmaları yapabilecekleri ve böylece sonuçların genellemesine daha fazla katkıda bulunabilecekleri önerilebilir. Bununla beraber saha çalışmalarının tekrarlı ve farklı hizmet türleriyle de (Fast-food, ızgara ürünler, hamur işleri, sulu yemek vs.) yapılarak sonuçlarının değerlendirilebileceği düşünülmektedir. 


\section{Introduction}

It is claimed that coronavirus (COVID-19) spread from animal to human in a seafood and livestock market in Wuhan, China in December 2019, and then spread from person to person through droplet or contact (Üstün and Özçiftçi, 2020). The epidemic spread turned into a pandemic due to the fact that countries were unprepared for the COVID-19 epidemic and that's why there were some delays and confusion in the measures to be taken, and that transmission rate of the disease is high as well (VanderWeele et al., 2020).

Countries closed their borders in order to stop the spread and to ensure their own isolation, restricted free movement within the country and thus tried to minimize sociocultural interaction against COVID-19, which has affected the whole world at an unexpected rate. Some radical measures against COVID-19 were also taken in Turkey and are continuing to be taken. The most important of these measures include travel restrictions, curfews on people within a certain age range (over 65 and under 20), quarantine of areas where the virus is widespread, temporary closure of many workplaces, social isolation, no contact with any objects and/or people and social distance (TR Ministry of Interior, 2020).

It is inevitable that these radical and extraordinary measures will cause some changes in people's lifestyles, habits and behaviours. One of these changes is envisaged to be in takeaway orders. This is because, activities of many businesses are temporarily suspended as mentioned above. And food and beverage companies are the leading ones among them. The on-site service of these food and beverage companies has been suspended, and they are only allowed to provide takeaway service. It is estimated that both the curfew restrictions and allowing food and beverage establishments to only provide takeaway services increase the frequency of people ordering takeaway.

It is inevitable that the activities of food and beverage businesses that provide takeaway service before COVID-19 have increased due to the reasons mentioned above. In addition, it is natural that there are some deficiencies and setbacks arising from the inexperience of the enterprises that started takeaway service for the first time by necessity due to COVID-19. Again, during COVID-19, it is a foreseeable fact that the sensitivity of customers' expectations of hygiene, health, payment, and delivery speed will possibly increase. Due to these and similar reasons, it is assumed that there may be a change in customer complaints in this period.

Customer complaint is defined as a negative feedback that emerges after purchase and means that their expectations are not met. Businesses view customer complaints as one of the most important communication tools between the customer and the business. The reason for this is that customer complaints are evaluated as direct tips from customers without waiting for other warnings about the market for businesses (Demirel, 2007). Businesses regard customer complaints as a fast and economical feedback mechanism that they will use in the production stage, service process and while focusing on the market in order to meet their customers' needs in the most ideal way. In this respect, businesses consider customer complaints as a marketing tactic (Barlow and Moller, 2009; Fisk, 2010). It is claimed that businesses that consider customer complaints an opportunity and can satisfy their customers by making use of this opportunity correctly can regain their customers (Y1lmaz et al. 2016). For this reason, it is claimed that the satisfaction of the customer in purchasing goods and services is as important as the satisfaction of the customer after the complaint (Kuo and $\mathrm{Wu}, 2012$ ).

According to research, it is suggested that an increase of 0.02 in customer retention may result in a decrease of 0.10 in general expenses and thus a profit growth in the same rate (Odabaş1, 2009). For this reason, it is extremely important for businesses not to miss customers 
for whom they have spent time, effort and money and to continue to do so. In addition, it is argued that satisfaction and loyalty of customers whose complaints are evaluated and resolved are higher compared to their level of satisfaction and loyalty before their complaints (Bailey, 1994).

As can be understood from the explanations made above, it is extremely important for both customers and businesses to consider customer complaints and resolve them immediately. From this point of view, the present study will examine whether the complaints of customers who receive takeaway service have changed during COVID-19, and if so, in which direction they have changed. Thus, in line with the scientific results, recommendations can be made to both businesses and researchers who plan to work in this field.

\section{Literature Review}

In the literature review, it has been observed that the studies conducted on the complaints of customers who receive takeaway service directly are quite limited, but there are a large number of studies on customer complaints in food and beverage establishments. Some of these studies are given below in a chronological order.

Çuhadar and Aşıroğlu (2019) examined online customer reviews and evaluations made on yemeksepeti.com website for an international pizza delivery business operating in Eskişehir. In the study, a total of 695 online reviews were examined, and the results indicated that the customers mainly commented on taste, service, and speed.

Koçoğlu and Kıyıcı (2018) analyzed the complaint behaviours of restaurant customers in Ankara through the data they obtained from 604 restaurant customers. According to the results of the analysis, it was determined that the majority of the customers reported their complaints to the restaurant management first, that they were pleased to be provided with feedback regarding their complaints, but that they were thinking to change their restaurant preferences if their complaints were not resolved. In addition, it was found that complaint behaviours differed depending on the demographic characteristics of the customers (gender, age, marital status, education level, and income status).

A study conducted by Şahin et. al. (2018) in Alaçatı on the e-complaint behaviours of Gastronomy tourists, it was found that customers who experienced the restaurants operating in Alaçatı had complaints about the problems caused by the pricing most. It was determined that these complaints were related to high prices, the gap between the service provided and the price requested, and the lack of information about prices in the menus. In addition, it was observed that complaints about the problems arising from the product should not be underestimated, and that especially the complaints such as the presence of different food odours in the ordered food, and the lack of ergonomic restaurant furniture were repeated frequently.

Erdem and Yay (2017) analyzed the customer complaints on tripadvisor.com regarding the restaurants operating in Antalya. According to 106 reviews of 5 restaurants which were examined, the restaurant customers complained about the staff, food and beverages, service, price, service environment and menu, respectively.

The complaints shared on tripadvisor.com for food and beverage businesses operating in Kahramanmaraş were examined by Taştan and Kızılcık (2017). The results of the analysis indicated that the complaint elements centred upon the category of complaints related to food and beverages, and the taste element was targeted most in this context. 
Güler et al. (2016) analyzed the customer complaints on tripadvisor.com about businesses serving local foods in Mersin and Hatay. According to the results of the analysis, it was observed that the complaints mostly gathered under the dimensions of food problems, service delivery, staff problems and other problems. It was determined that the complaints under these dimensions arose due to problems of taste, personnel attitude, food authenticity, and fair price.

A research on customer complaint behaviours was carried out by Albayrak (2013) in first class restaurants in Istanbul. The results revealed that the customers mostly encountered problems with the staff and that the complaint behaviours of the customers differed according to their demographic characteristics (age, gender, education, income, etc.).

As can be seen in the studies listed above, the complaints of the restaurant customers are concentrated on subjects related to price, taste, service quality, menu variety, service environment and food authenticity. As revealed in the studies, it is understood that the customers care about the positive feedback about their complaints, and that they consider changing their restaurant preferences if there is no feedback or the problem is not solved.

In line with these data, the study sought an answer to two main research questions:

RQ1: What complaints do takeaway customers have?

RQ2: Have the complaints of takeaway customers changed during COVID-19?

\section{Method}

Content analysis based on coding was employed in the study as the method. Content analysis starts by determining the analysis categories of the message (customer complaint within the scope of this study). Categories of analysis are related to the aspects that are interested in the message and aimed to be revealed (Bilgin, 2006). In this way, it becomes possible to reach the concepts and relationships that can explain the collected data (Yildirım and Şimşek, 2013).

Within the scope of the study, the complaints of customers who ordered food from www.yemeksepeti.com were scanned on www.sikayetvar.com.tr. As of the date of the scanning, there were a total of 3138 complaints on the website. In order to achieve meaningful statistical results in line with the purpose of the study, a total of 800 complaints were scanned, 400 of which were backwards and 400 of which were forward from March 21, 2020.

The reason for choosing the starting date as March 21, 2020 is the assumption that COVID-19 process started in Turkey as of this date. This is because on March 21 the Ministry of Interior issued an order to declare that people within a certain age range were prohibited from going out onto the streets and many businesses, including food and beverage businesses, were suspended. The measures and regulations continued in the circulars of the Ministry of Interior that are issued after this date, and in these circulars it was stated that entry and exit was banned for a total of 31 provinces, including 30 provinces with metropolitan status and the province Zonguldak, that weekend curfews would be imposed, and wearing masks were made mandatory (T.R. Ministry of Interior, 2020). While scanning the complaints, the researchers tried to determine the gender of the users who made complaints, which would make it possible to examine whether the customer complaints differed in terms of gender. During the backward scanning made from March 21, 2020, records of 400 complaints were obtained on February 1, 2020 (49 days). In the forward scanning made from March 21, 2020, records of 400 complaints were obtained on April 27, 2020 (38 days). 
The complaints obtained were coded separately in two groups as before COVID-19 and during COVID-19. Studies by Liu and Jang (2009) and by Güler et al. (2016) were benefited during the coding process. In the light of these studies, the complaints scanned were collected under a total of nine codes. These codes were determined as payment, speed, taste, hygiene, health, heat, incomplete delivery, behaviour and return, respectively.

\section{Analysis and Findings}

The analyses started with the transfer of the scanned data to the computer. The results of the analysis performed on the transferred data and the findings are illustrated in tables below.

Table 1: Gender Distribution of The Customers Who Made Complaints

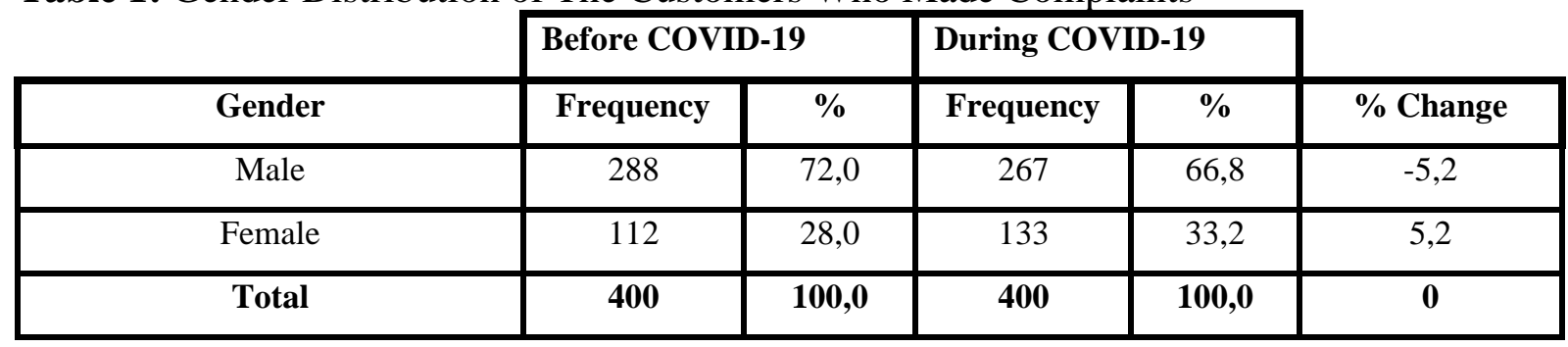

Table 1 comparatively presents the gender distribution of the customers who made complaints before COVID-19 and during COVID-19. As can be seen in the table, 288 of 400 complaints were made by males before COVID-19 while this number decreased to 267 during COVID-19. On the other hand, the number of females who made complaints went up to 133 during COVID-19 whereas it was 112 before COVID-19. These figures show that the complaints of females increased compared to males during COVID-19.

Table 2: The Themes of the Complaints Made By The Customers

\begin{tabular}{|c|c|c|c|c|c|}
\cline { 2 - 6 } \multicolumn{1}{c|}{} & \multicolumn{2}{c|}{ Before COVID-19 } & \multicolumn{2}{c|}{ During COVID-19 } & \multirow{2}{*}{} \\
\hline Complaint Themes & Frequency & $\mathbf{\%}$ & Frequency & Frequency & \% Change \\
\hline Behaviour & 99 & 24,8 & 24 & 6,0 & $-18,8$ \\
\hline Payment & 76 & 19,0 & 25 & 6,3 & $-12,7$ \\
\hline Speed & 74 & 18,5 & 65 & 16,3 & $-2,2$ \\
\hline Return & 54 & 13,5 & 14 & 3,5 & $-10,0$ \\
\hline Incomplete Delivery & 42 & 10,5 & 36 & 9,0 & $-1,5$ \\
\hline Hygiene & 21 & 5,3 & 67 & 16,8 & 11,5 \\
\hline Taste & 17 & 4,3 & 70 & 17,5 & 13,2 \\
\hline Heat & 14 & 3,5 & 37 & 9,3 & 5,8 \\
\hline Health & 3 & 0,8 & 62 & 15,5 & 14,7 \\
\hline Total & $\mathbf{4 0 0}$ & $\mathbf{1 0 0}$ & $\mathbf{4 0 0}$ & $\mathbf{1 0 0}$ & $\mathbf{0}$ \\
\hline
\end{tabular}

Table 2 illustrates the themes of the complaints made by the takeaway customers and the percent change before and after COVID-19. As can be seen in the second column in the table, the three most common themes of the complaints made by the customers before COVID19 included behaviour, payment and speed, respectively, and they were followed by return, incomplete delivery and hygiene. As revealed in the same column, the three lowest ranking themes were taste, heat and health, respectively. When we look at the fourth column, which contains the figures related during COVID-19 in the table, it is seen that the first three themes that the customers complained about most in during COVID-19 were taste, hygiene and speed, 
respectively, which were followed by health, heat and incomplete delivery, respectively. In the same column, the lowest ranking themes included payment, behaviour and return, respectively.

The last column of the table demonstrates the percentage changes in the themes of customer complaints during COVID-19. As pointed out in the column, the greatest negative percentage change in the themes of customer complaints was observed in behaviour $(18.8 \%)$, payment (12.7) and return (10.0), respectively. As can be seen in the same column, the greatest positive change was determined to be in health $(14.7 \%)$, taste $(13.2 \%)$ and hygiene $(11.5 \%)$, respectively.

Table 3: The Themes of Customer Complaints by Gender

\begin{tabular}{|c|c|c|c|c|c|c|}
\hline \multirow[b]{2}{*}{$\begin{array}{l}\text { Themes of the } \\
\text { complaints }\end{array}$} & \multirow[b]{2}{*}{ Gender } & \multicolumn{2}{|c|}{ Before COVID-19 } & \multicolumn{2}{|c|}{ During COVID-19 } & \multirow[b]{2}{*}{ \% Change } \\
\hline & & Frequency & $\%$ & Frequency & $\%$ & \\
\hline \multirow{2}{*}{ Behaviour } & Male & 74 & 25,7 & 19 & $\overline{7,1}$ & $-18,6$ \\
\hline & Female & 25 & 22,3 & 5 & 3,8 & $-18,5$ \\
\hline \multirow{2}{*}{ Payment } & Male & 57 & 19,8 & 20 & 7,5 & $-12,3$ \\
\hline & Female & 19 & 17,0 & 5 & 3,8 & $-13,2$ \\
\hline \multirow{2}{*}{ Speed } & Male & 48 & 16,7 & 57 & 21,3 & 4,6 \\
\hline & Female & 26 & 23,2 & 8 & 6,0 & $-17,2$ \\
\hline \multirow{2}{*}{ Return } & Male & 43 & 14,9 & 13 & 4,9 & -10 \\
\hline & Female & 11 & 9,8 & 1 & 0,8 & -9 \\
\hline \multirow{2}{*}{ Incomplete delivery } & Male & 28 & 9,7 & 28 & 10,5 & 0,8 \\
\hline & Female & 14 & 12,5 & 8 & 6,0 & $-6,5$ \\
\hline \multirow{2}{*}{ Hygiene } & Male & 15 & 5,2 & 38 & 14,2 & 9 \\
\hline & Female & 6 & 5,4 & 29 & 21,8 & 16,4 \\
\hline \multirow{2}{*}{ Taste } & Male & 13 & 4,5 & 48 & 18,0 & 13,5 \\
\hline & Female & 4 & 3,6 & 22 & 16,5 & 12,9 \\
\hline \multirow{2}{*}{ Heat } & Male & 8 & 2,8 & 23 & 8,6 & 5,8 \\
\hline & Female & 6 & 5,4 & 14 & 10,5 & 5,1 \\
\hline \multirow{2}{*}{ Health } & Male & 2 & 0,7 & 21 & 7,9 & 7,2 \\
\hline & Female & 1 & 0,9 & 41 & 30,8 & 29,9 \\
\hline \multirow{2}{*}{ Total } & Male & 288 & 100 & 267 & 100 & - \\
\hline & Female & 112 & 100 & 133 & 100 & - \\
\hline
\end{tabular}

Table 3 presents the distribution and changes of customer complaints by gender before and during COVID-19. In the table, the 3rd and 4th columns include the frequency and percentage distribution of the complaints before COVID-19, and the 5th and 6th columns demonstrate the frequency and percentage distribution of the complaints during COVID-19. As seen in the 3rd and 4th columns, the ranking of the complaints made by males before COVID19 is as behaviour, payment, speed, return, incomplete delivery, hygiene, taste, heat, and health, respectively, while the ranking of the complaints made by females is listed as speed, behaviour, payment, incomplete delivery, return, hygiene, heat, taste, and health, respectively.

When the 5th and 6th columns are examined in the table, the priority ranking of males during COVID-19 is as speed, taste, hygiene, incomplete delivery, heat, health, payment, behaviour and return, respectively. However, the ranking of the complaints made by females is given in the same columns as health, hygiene, taste, heat, speed, incomplete delivery, behaviour, payment, and return, respectively.

The last column of the table illustrates the percentages of change in customer complaints based on gender during COVID-19. As revealed in the column, the biggest difference in the percentages of change based on gender occurred in health $(22.7 \%)$, speed $(22.3 \%)$ and hygiene (7.4\%), respectively. 


\section{Conclusion and Recommendations}

As stated in the method section of the research, 400 complaints were recorded within 49 days before COVID-19 and 400 complaints were recorded in 38 days during COVID-19. This shows that the records of customer complaints increased during COVID-19. It is understood that an average of $8,16(400 / 49=8,16)$ customer complaints were made before COVID-19, and this number increased to $10.52(400 / 38=10.52)$ during COVID-19. This increase may have resulted from the workload experienced in takeaway service, or it may have been caused by certain sensitivities of the customers in this extraordinary process. It is recommended that the companies that provide takeaway service should not ignore this increase in complaints, which are essential in terms of customer satisfaction and customer loyalty, and should work to identify and eliminate the problems related to these complaints immediately.

As pointed out in Table 1 under the title of analysis and findings, the number of males who recorded complaints during COVID-19 decreased from 288 to 267, while the number of females increased from 112 to 133. This situation may be due to the sensitivity of female customers especially to health and hygiene during COVID-19. As can be seen in Table 3, these two themes are the two highest ranking themes. Companies that provide takeaway service may be suggested to pay more attention to health and hygiene issues in this process and beyond. In addition, when the COVID-19 is over, researchers are advised to conduct similar studies and compare the results.

As revealed in Table 2, while the highest ranking four themes of the customer complaints before COVID-19 include behaviour, payment, speed, and return, this order changes during COVID-19 as taste, hygiene, speed, and health. It is estimated that this change may have been caused by the sensitivity of customers to health and hygiene issues and the workload experienced in the companies that provide takeaway service with the impact of the extraordinary process. In this context, businesses are recommended not to compromise on health and hygiene issues while trying to meet the heavy workload, not to neglect both their working hours and working conditions, and to activate material and moral practices that increase their motivation. Researchers are advised to conduct studies on the commitment and motivation levels of those working in takeaway service and their leave and/or burnout levels and then to compare the results.

As pointed out in Table 3, the most important difference in the ranking of the complaint themes based on gender occurs in health, hygiene, and speed during COVID-19. This difference is in favour of female customers, so it is recommended that businesses that provide takeaway service should pay attention to these issues that should already be taken into consideration, especially in the orders of female customers.

The study was carried out in a limited time and through the content analysis of the online customer complaints. It can be suggested that researchers do field studies on the subject and thus contribute more to the generalization of the results. In addition, the results of the field studies can be evaluated by conducting studies repeatedly and with different types of services (Fast food, grilled products, pastries, stew or vegetable meals etc.).

\section{References}

Albayrak, Y. A. (2013). Restoran işletmelerinde müşteri şikâyetleri ve şikâyete ilişkin davranışlar. Paradoks Ekonomi, Sosyoloji ve Politika Dergisi. 9(2), 26-51.

Bailey, D. (1994). Recovery from Customer Service Shortfall. Managing Service Quality.4(6), 25-28. 
Barlow, J. \& Moller C. (2009). Her şikâyet bir armağandır. İstanbul: Rota Yayın Yapım Tanıtım Tic. Ltd. Şti.

Bilgin, N. (2006). Sosyal bilimlerde içerik analizi. Ankara: Siyasal Yayınevi.

Çuhadar, M. \& Aşıroğlu, B. (2019). Zincir fastfood işletmelerine yönelik çevrimiçi değerlendirmelerin analizi: Eskişehir örneği. 20. Ulusal 4. Uluslararası Turizm Kongresi. T.C. Anadolu Üniversitesi Yayınları No: 3935. 415-422.

Demirel, Y. (2007). Müşteri ilişkileri yönetimi ve bilgi paylaşımı. İstanbul: IQ Kültür Sanat Yayınc1lık.

Erdem, Ö. \& Yay, Ö. (2017). Tripadvisor'daki müşteri şikâyetlerinin değerlendirilmesi: Antalya örneği. Journal of Tourism and Gastronomy Studies. 5. 227-249.

Fisk, P. (2010). Müşteri dehası. İstanbul: Kapital Medya Hizmetleri A.Ş.

Güler, O., Birdir, K. \& Dalgıç, A. (2016). Tripadvisor.com'da Yer Alan Restoran Şikâyetlerinin Analizi: Mersin ve Hatay'da Yöresel Yiyecek Sunan Restoranlara Yönelik Bir Araştırma. Journal of Tourism and Gastronomy Studies. 4. 153-153.

Koçoğlu, C. \& Kıycı, Ş. (2018). Restoran işletmelerinde müşteri şikâyet davranışlarının analizi: ankara ilinde bir araştırma. Journal of Tourism and Gastronomy Studies. 6, 437-450.

Kuo Y. F. \& Wu, C. M. (2012). Satisfaction and post-purchase intentions with service recovery of online shopping websites: perspectives on perceived justice and emotions. Internaional Journal of Information Management, 32(2), 127-138.

Liu, Y. \& Jang, S. S. (2009). Perceptions of chinese restaurants in the US: What affects customer satisfaction and behavioural intentions?. International Journal of Hospitality Management, 28(3), 338-348.

Odabaş1, Y. (2009). Satış ve pazarlamada müşteri ilişkileri yönetimi (CRM). İstanbul: Sistem Yayınc1lık.

Şahin, S., Girgin, G., Kazoğlu, İ. \& Coşkun, G. (2018). Gastronomi turistlerinin e-şikâyet davranışları üzerine bir araştırma: alaçatı örneği. Journal of Tourism and Gastronomy Studies. 6. 68-82.

Tastan, H. \& Kızılcık, O. (2017). Kahramanmaraş’ta bulunan yiyecek içecek işletmelerine yönelik trıpadvısor.com'da paylaşılan şikâyetlerin sınıflandırılması. Ç. Ü. Sosyal Bilimler Enstitüsü Dergisi, 26, 270-284.

T.C. İçişleri Bakanlığı (2020). https://www.icisleri.gov.tr/. (Erişim Tarihi: 20.05.2020)

Üstün, Ç. \& Özçiftçi, S. (2020). COVID-19 pandemisinin sosyal yaşam ve etik düzlem üzerine etkileri: Bir değerlendirme çalışması. Anatolian Clinic the Journal of Medical Sciences , 25 (1), 142-153.

VanderWeele TJ., Chen Y., Long K., Kim ES., Trudel-Fitzgerald C. \& Kubzansky LD. (2020). Positive epidemiology?. Epidemiology. 31(2):189-193.

Yıldırım, A. \& Şimşek, H. (2013). Sosyal bilimlerde nitel araştırma yöntemleri. Ankara: Seçkin Yayıncilik. 
Yılmaz, V., Arı, E. \& Doğan, R. (2016). Online alışverişte müşteri şikâyet niyetleri ve davranışlarının yapısal eşitlik modeli ile incelenmesi. Journal of Yaşar University, 11(42), 102-112. 